\title{
Student's Perception of Teachers' Knowledge, Attitude and Skills in the Teaching of Technical Drawing in Edo and Delta States, Nigeria
}

\author{
Patrick Oyaimare Uddin ${ }^{1}$, Raymond Uwameiye ${ }^{1}$, Samuel Chukwuemeka Nwachokor ${ }^{2}$
}

\author{
${ }^{1}$ Ambrose Alli University \\ 70 Benin Auchi Road, P. M. B 14, Ekpoma, Edo State, Nigeria \\ ${ }^{2}$ University of Nigeria, Nsukka \\ Nsukka Road, 410001, Nsukka, Enugu State, Nigeria
}

DOI: $10.22178 /$ pos. $46-4$

LCC Subject Category:

LB2331.7-2335.8

Received 20.04.2019

Accepted 27.05.2019

Published online 31.05.2019

Corresponding Author:

Patrick Oyaimare Uddin

uddinpatrick@gmail.com

(c) 2019 The Authors. This article

is licensed under a Creative

Commons Attribution 4.0 License

(c) (1)

\begin{abstract}
This paper focuses on students' perception of teachers' knowledge, attitude and skills in the teaching of technical drawing in Edo and Delta States of Nigeria. The empirical results are based on a quantitative survey of 300 students who were asked to evaluate their technical drawing teachers. The findings show that technical drawing students perceived their technical drawing teachers to have some negative attitudes because they disliked some of their students $(2.18 \pm 1.17)$, rarely show concern when students have problems of poor understanding of some technical concepts $(1.27 \pm 1.13)$ and always waited for students to remind them of their teaching periods $(2.30 \pm 1.15)$. Some of the positive attitudes attributed to their teachers were; they always encourage good laboratory habits among technical drawing students $(3.39 \pm 0.93)$ and encouraged parents to equip their children with the required materials they need for effective learning of technical drawing $(3.34 \pm 0.91)$. Further, students perceived their teachers effective in preparing and organizing lesson notes adequately $(3.27 \pm 0.93)$ as such applied facts and principles to problem-solving $(3.31 \pm 0.86)$. The findings support the conclusion that there are aspects of teachers' knowledge, attitude and skills in teaching technical drawing that is less than excellent and in need of further enhancement.
\end{abstract}

Keywords: students' perception; teachers' performance; teacher behaviour; technical drawing.

\section{INTRODUCTION}

Teaching and learning are main aspects of learning activities that affect student achievement [13]. Effective teaching and learning are indicators of quality teachers and quality teaching performance which are all determining factors of a well-designed educational system [11, 14]. Teaching involves many skills and attitudes expressed through the behaviour of the teacher and influential in shaping the behaviour of the learner [12]. The tasks and duties of a teacher vis-à-vis his expectations may be at variance with the students' perception.

The role of students in the instructional process is critical as their perception could influence their attitude toward technical drawing or any other technical education subjects [4]. Perception is the way people judge others with who they are in contact [2]. Generally, students usually judge their school teachers in areas such as the teachers' knowledge of the subject matter, communication ability, the choice of appropriate teaching method and the general classroom management skills [4]. A teacher who is rated on these indices at high level is likely to enjoy the confidence, respect and admiration of his students based on their perception. The knowledge of the way the students think and perceive can aid the teacher to reflect upon and adjust his teaching strategies to enhance students' understanding and achievement.

Student ratings have been used for many years to evaluate the performance of teachers in their classes [19]. Student's perception of teachers' performance has also been regarded as an important factor in predicting teachers' performance and student learning $[6,7,8,17]$ such as teachers' knowledge, attitude and teaching skills 
and academic achievement. Therefore, it can be anticipated that teachers' performance in teaching as manifested by students' perception will lead to both teacher improvement in-role and extra-role performance in teaching and students' learning and academic achievements [4].

Purpose of the study and research question. The broad objective of the present study is to investigate students' perception of teachers' knowledge, attitude and skills in the teaching of technical drawing in Edo and Delta States of Nigeria. To this end, the specific objectives of this study are to:

- ascertain students' rating of their teachers' attitude in the teaching of technical drawing in technical colleges; and

- ascertain students' rating of their teachers on the indices of knowledge and skills of teachers' effectiveness in the teaching of technical drawing in the technical colleges.

The study sought to answer the following questions:

1. How do the students rate their technical drawing teachers' attitude in the teaching of technical drawing in technical colleges?

2. How do the technical drawing students rate their teachers on the indices of knowledge and skills of teachers' effectiveness in the teaching of technical drawing in the technical colleges?

\section{METHODOLOGY}

The study employed a descriptive survey research design. The population for the study consisted of vocational year 1-3 students of all the technical colleges in Edo and Delta States of Nigeria. The ten (10) old public technical colleges in both states were used. The new public technical colleges were excluded because of poor infrastructures and human resource development. Out of the eight hundred (800) students' population, three hundred (300) students (37.5\%) were used. Thirty (30) students were randomly selected per college. In the randomization, 8 students were selected from Electrical Installation, 8 students in Motor Vehicle Mechanic, 7 students in Block-laying/Concreting and 7 students in Carpentry/Joinery. Questionnaire was used to elicit response from respondents. The researcher used a four scale response which was scored as 1 point to Strongly Disagree (SD) 2 point to Disagree (D), 3 point to Agree (A) and 4 point to Strongly Agree (SA). The mean cut-off point was 2.5. The Statistical Package for the Social Sciences (SPSS) software was used for analysis.

\section{RESULTS AND DISCUSSION}

Table 1 shows that students agree that their teachers have negative attitude in the teaching of technical drawing in technical colleges for items $11,12,13,14,15$ and 19.

Table 1 - Students perception of teachers' attitude towards teaching of technical drawing in technical colleges

\begin{tabular}{|c|c|c|c|c|}
\hline S/No. & Attitude & $\mathrm{X}$ & SD & Decision \\
\hline 11 & Allow family or personal problems to disturb class work & 2.04 & 1.14 & Negative \\
\hline 12 & Always wait for students to remind me of my teaching periods & 2.30 & 1.15 & Negative \\
\hline 13 & Dislike some of my students & 2.18 & 1.17 & Negative \\
\hline 14 & $\begin{array}{l}\text { Rarely show any concern when students have problems of poor } \\
\text { understanding of some technical concepts }\end{array}$ & 1.27 & 1.13 & Negative \\
\hline 15 & Do not encourage students to be punctual to class & 1.69 & 1.26 & Negative \\
\hline 16 & as punctually & 2.18 & 1.03 & Negative \\
\hline 17 & Encourage good laboratory habits am & 3.39 & 0.93 & Positive \\
\hline 18 & $\begin{array}{l}\text { Feel very enthusiastic to mark technical drawing assignments given to } \\
\text { students }\end{array}$ & 3.18 & 0.96 & Positive \\
\hline 19 & e technical drawing topics taught to students & 1.70 & 1.15 & Negative \\
\hline 20 & $\begin{array}{l}\text { Encourage parents to equip their children with the required materials they } \\
\text { need for effective learning of technical drawing }\end{array}$ & 3.34 & 0.91 & Positive \\
\hline & Overall Mean & 2.33 & 1.08 & \\
\hline
\end{tabular}

That is, teachers allow family or personal problems to disturb class work has a mean of 2.04; always wait for students to remind them of their teaching periods has a mean of 2.30 and dislike some of their students has a mean of 2.18. Rarely shows any concern when students have prob- 
lems of poor understanding of some technical concepts has a mean score of 1.27 , do not encourage students to be punctual to class has a mean of 2.30 and show dislike for some technical drawing topics taught to students has a mean of 2.30 .

On the other hand, Table 1 also shows that students agree that their teachers have positive attitude in the teaching of technical drawing in technical colleges for items numbers 17, 18 and 20. That is, their teacher encourages good laboratory habits among technical drawing students, has a mean of 3.39. Furthermore, teachers feel very enthusiastic to mark technical drawing an assignment given to students has a mean of 3.18 and encourage parents to equip their children with the required materials they need for effective learning of technical drawing has a mean of 3.34.
Data in Table 1 also reveals that, the students rated their technical drawing teachers' attitude effective in three out of 10 teachers' attitude towards the teaching of technical drawing in technical colleges of Edo and Delta States. Table 1 concluded with the overall mean score of 2.33 that the teachers have negative attitude towards the teaching of technical drawing in technical colleges of Edo and Delta States.

Table 2(a) shows that the students perceived their teachers effective in items numbers 21 and 23 in lesson planning. That is, prepare and organize lesson notes adequately has a mean score of 3.27 and always state lesson objectives in behavioural terms in all the technical drawing topics taught to students has a mean score of 3.19. Students rated their teacher not effective in item no 22 i.e. select instructional equipment and other instructional aids for effective teaching of technical drawing has a mean score of 0.70 .

Table 2(a) - Students perception of teachers' effectiveness in the indices of teachers' knowledge and skills in the teaching of technical drawing

\begin{tabular}{|c|c|c|c|c|}
\hline S/No. & Attitude & $\mathrm{X}$ & SD & Decision \\
\hline & (1) Lesson Planning & & & \\
\hline 21 & Prepare and organize lesson notes adequately & 3.27 & 0.93 & Effective \\
\hline 22 & $\begin{array}{l}\text { Select instructional equipment and other instructional aids for effective teaching } \\
\text { of technical drawing }\end{array}$ & 0.70 & 0.90 & Not Effective \\
\hline \multirow[t]{2}{*}{23} & $\begin{array}{l}\text { Always state lesson objectives in behavioural terms in all the technical drawing } \\
\text { topics taught to students }\end{array}$ & 3.19 & 0.91 & Effective \\
\hline & (2) Teaching Techniques & & & \\
\hline 24 & Prefer the use of lecture method to inquiry or demonstration method & 1.07 & 1.05 & Not Effective \\
\hline 25 & Do most of the talking while the students do very little talking & 0.97 & 0.98 & Not Effective \\
\hline 26 & Do not assist students to find solution to their problems & 1.61 & 1.14 & Not Effective \\
\hline 27 & $\begin{array}{l}\text { Give take home assignments weekly on any technical drawing topic covered in } \\
\text { class }\end{array}$ & 3.33 & 0.94 & Effective \\
\hline 28 & $\begin{array}{l}\text { Offer adequate explanation/guidelines on how students should solve the home } \\
\text { work given to them }\end{array}$ & 3.27 & 0.90 & Effective \\
\hline 29 & $\begin{array}{l}\text { Always ensure that students do the technical drawing take home assignment } \\
\text { given to them }\end{array}$ & 3.52 & 0.81 & Effective \\
\hline 30 & $\begin{array}{l}\text { Allow students enough opportunity to ask questions on concepts not clearly } \\
\text { understood by them }\end{array}$ & 3.17 & 0.91 & Effective \\
\hline 31 & Shout students down when they ask questions & 1.85 & 1.20 & Not Effective \\
\hline 32 & Encourage students to participate in group discussions & 3.10 & 0.93 & Effective \\
\hline \multirow[t]{2}{*}{33} & Give chalkboard summary of any technical drawing topic covered in class & 3.18 & 0.99 & Effective \\
\hline & (3) Use of Questions & & & \\
\hline 34 & Recall facts and principles & 3.17 & 0.93 & Effective \\
\hline 35 & Apply facts and principles to problem solving & 3.31 & 0.86 & Effective \\
\hline 36 & Make direct observation on student's performance & 3.24 & 0.90 & Effective \\
\hline 37 & Interpret recorded drawing to students & 3.11 & 0.90 & Effective \\
\hline \multirow[t]{2}{*}{38} & Make students understand the purpose of any drawing & 3.40 & 0.89 & Effective \\
\hline & (4) Use of Models/Teaching Aids & & & \\
\hline 39 & Construct and improvise teaching/learning aids & 0.90 & 0.92 & Not Effective \\
\hline 40 & $\begin{array}{l}\text { Use teaching aids to facilitate students understanding of some difficult and } \\
\text { abstract concepts in technical drawing }\end{array}$ & 0.90 & 0.94 & Not Effective \\
\hline
\end{tabular}




\begin{tabular}{|c|c|c|c|c|}
\hline S/No. & Attitude & $\mathrm{X}$ & SD & Decision \\
\hline & (5) Use of Practical/Demonstration Activity & & & \\
\hline 41 & Involves students in practical activities in all practical oriented topics & 2.42 & 0.79 & Not Effective \\
\hline \multirow[t]{2}{*}{42} & $\begin{array}{l}\text { Demonstrate each activity before the students are called upon to perform on } \\
\text { their own }\end{array}$ & 2.23 & 0.83 & Not Effective \\
\hline & (6) Evaluation Techniques & & & \\
\hline 43 & Set examinations on those topics not taught in class & 1.75 & 1.18 & Not Effective \\
\hline 44 & Usually award marks to students without actually setting any examinations & 1.89 & 1.16 & Not Effective \\
\hline 45 & Award marks without marking their scripts. & 1.98 & 1.14 & Not Effective \\
\hline 46 & Always assist some students in the examination hall & 2.01 & 1.19 & Not Effective \\
\hline 47 & Carry out on the spot assessment of students during prac & 2.85 & 1.01 & Effective \\
\hline 48 & $\begin{array}{l}\text { Usually award marks to students for their approach to task, that is, initiative and } \\
\text { ability to give and receive instructions }\end{array}$ & 2.93 & 1.00 & Effective \\
\hline 49 & $\begin{array}{l}\text { Assess students' ability to handle equipment, overcoming difficulties, } \\
\text { thoroughness, accuracy and neatness }\end{array}$ & 3.24 & 0.86 & Effective \\
\hline 50 & $\begin{array}{l}\text { Assess students' ability to translate data, that is, calculations preparation of plans } \\
\text { and use of scales in drawing }\end{array}$ & 3.21 & 0.86 & Effective \\
\hline \multirow[t]{2}{*}{51} & $\begin{array}{l}\text { Make sure that students do not cheat during any of the technical drawing } \\
\text { examination }\end{array}$ & 3.27 & 0.97 & Effective \\
\hline & (7) Co-Curricular Activities & & & \\
\hline 52 & Visit the homes of problem children to discuss their proble & 2.34 & 1.13 & Not Effective \\
\hline 53 & Show interest in parents/teachers association. & 3.09 & 1.08 & Effective \\
\hline 54 & Maintain a very cordial relationship with colleagues and oth & 3.22 & 0.87 & Effective \\
\hline 55 & Maintain a good rapport with the principal & 3.17 & 0.90 & Effective \\
\hline 56 & $\begin{array}{l}\text { Supervision of students on national, state or local activities like the National Day } \\
\text { Celebration, Health Week, Scout and Boys Brigade matters, etc. }\end{array}$ & 2.71 & 1.09 & Effective \\
\hline 57 & Take active part in schools/college debates & 2.75 & 1.07 & Effective \\
\hline 58 & Show keen interest in school games and other sporting activities. & 2.75 & 1.10 & Effective \\
\hline
\end{tabular}

Entries in Table 2(a) also indicates that in teaching techniques, the respondents rated their teachers effective in each items numbers 27, 28, $29,30,32$ and 33 . That is, give take home assignments weekly on any technical drawing topic covered in class has a mean score of 3.33; offer adequate explanation/guidelines on how students should solve the homework given to them has a mean score of 3.27 . In the same vein, always ensure that students do the technical drawing take home assignment given to them has a mean score of 3.52, allow students enough opportunity to ask questions on concepts not clearly understood by them, has a mean score of 3.17, encourage students to participate in group discussions has a mean score of 3.10 and give chalkboard summary of any technical drawing topic covered in class has a mean score of 3.18. In the same table as well, the respondents' shows that their teachers were not effective in items numbers 24, 25, 26 and 31. That is, prefer the use of lecture method to inquiry or demonstration method has a mean score of 1.07, do most of the talking while the students do very little talking has a mean score of 0.97 , do not assist students to find solution to their problems has a mean score of 1.61 and shout students down when they ask questions has a mean score of 1.85 .

In addition, Table 2(a) reveals that for the use of questions, the students rated their teachers effective in all the items numbers $34,35,36,37$, and 38. Recall facts and principles has a mean score of 3.17; apply facts and principles to problem solving has a mean score of 3.31; make direct observation on student performance has a mean score of 3.24; interpret recorded drawing to students has a mean score of 3.11 and make students understand the purpose of any drawing has a mean score of 3.40 .

Furthermore, Table 2(a) shows that for use of models/teaching aids, the respondents rated their teachers not effective in all items numbers 39 and 40. That is, construct and improvised teaching. Learning aids has a mean score of 0.90 and use teaching aids to facilitate students understanding of some difficult and abstract concepts in technical drawing has a mean score of 0.90 .

Also, Table 2(a) shows that for use of practical/demonstration activity, the students rated their teachers not effective in all the items num- 
bers 41 and 42 . That is, involves students in practical activities in all practical oriented topics has a mean score of 2.42 and demonstrate each activity before the students are called upon to perform on their own has a mean score of 2.23.

Table 2(a) added that, the respondents rated their teachers on evaluation techniques effective on items numbers 47, 48, 49, 50 and 51. Carry out on the spot assessment of students during practical drawing has a mean score of 2.85; usually award marks to students for their approach to task, that is, initiative and ability to give and receive instructions has a mean score of 2.93; assess students ability to handle equipment, overcoming difficulties, thoroughness, accuracy and neatness has a mean score of 3.24; assess students ability to translate data, that is, calculations preparation of plans and use of scales in drawing has a mean score of 3.21 and make sure that students do not cheat during any technical drawing examination has a mean score of 3.27. Also, the students rated their teachers not effective in items numbers $43,44,45$ and 46 . That is, set examinations on those topics not taught in class has a mean score of 1.75; usually award marks to students without actually setting any examinations has a mean score of 1.89; award marks without marking their scripts has a mean of 1.98 and always assist some students in the examination hall has a mean score of 2.01 .

Finally, Table 2(a) shows that in co-curricular activities, the respondents rated their teachers effective on items numbers 53, 54, 55, 56, 57 and 58 . Show interest in parents/teachers association has a mean score of 3.09; maintain a very cordial relationship with colleagues and other subject teachers has a mean score of 3.22; maintain a good rapport with the principal has a mean score of 3.17; supervision of students on national, state or local activities like the national day celebration, health week, scout and boys brigade matters etc. has a mean score of 2.17; while take active part in school/college debate has a mean score of 2.75 and show keen interest in school games and other sporting activities has a mean score of 2.75 . The respondents rated their teachers not effective in visit the homes of problem children to discuss their problems with their parents has a mean score of 2.34 .

Table 2(b) indicates that the students rated their teachers effective in three out of the seven indices of teachers' knowledge and skills in the teaching of technical drawing in technical colleges in
Edo and Delta States. That is, use of questions has overall mean score of 3.25; evaluation technique has overall mean score of 2.57 and a cocurricular activity has overall mean score of 2.86 . Also, the students rated their teacher not effective in lesson planning has overall mean score of 2.39; teaching techniques has an overall mean score of 2.31; use of models/teaching aids with overall mean score of 0.90 ; and in the use of practical/demonstration activity with overall mean score of 2.33 .

Table 2(b) - Summary of students' perception of teachers' effectiveness in the indices of teachers' knowledge and skills

\begin{tabular}{|c|c|c|c|c|}
\hline No & Variables & $\begin{array}{c}\text { Overall } \\
\text { Mean }\end{array}$ & SD & Decision \\
\hline 1 & Lesson Planning & 2.39 & 0.91 & $\begin{array}{l}\text { Not } \\
\text { Effective }\end{array}$ \\
\hline 2 & Teaching Techniques & 2.31 & 0.99 & \begin{tabular}{|l} 
Not \\
Effective
\end{tabular} \\
\hline 3 & Use of Questions & 3.25 & 0.90 & Effective \\
\hline 4 & $\begin{array}{l}\text { Use of Models/Teaching } \\
\text { Aids }\end{array}$ & 0.90 & 0.93 & \begin{tabular}{|l} 
Not \\
Effective
\end{tabular} \\
\hline 5 & $\begin{array}{l}\text { Use of } \\
\text { Practical/Demonstration } \\
\text { Activity }\end{array}$ & 2.33 & 0.81 & $\begin{array}{l}\text { Not } \\
\text { Effective }\end{array}$ \\
\hline 6 & Evaluation Techniques & 2.57 & 1.04 & Effective \\
\hline 7 & Co-Curricular Activities & 2.86 & 1.03 & Effective \\
\hline & Overall Mean & 2.40 & 0.94 & $\begin{array}{l}\text { Not } \\
\text { Effective }\end{array}$ \\
\hline
\end{tabular}

Table 2(b) shows that the students perceived that the teachers were not effective in four out of seven indices of teachers' knowledge and skills in the teaching of technical drawing in technical colleges in Edo and Delta States and the overall mean score of 2.40 concludes that the teachers were not effective in the teaching of technical drawing in technical colleges in Edo and Delta States.

From the analysis of research question one; the students perceived their technical drawing teachers' attitude positive in three out 10 teachers' attitudes towards the teaching of technical drawing in Edo and Delta States. The implication of this finding is that most of the technical drawing teachers have negative attitude in the teaching of technical drawing. The attitude of the technical drawing teachers helps to judge the teachers' effectiveness in his/her teaching of the subject. This finding is corroborated by Barness (2005) who reported that attitude is the curios- 
ity, interest, risk taking, objectivity, precision, confidence, perseverance, satisfaction, responsibility, consensus and collaboration as displayed by the teacher. In order words, attitude is the extent to which the technical drawing teacher shows that he is willing to do more than the minimum or the average of his job and that he enjoys it. It includes whether the teacher is sympathetic to his/her students plight, especially to low achievers, carries home unmarked students' assignment, project and others to complete at home at his/her leisure or leave the school compound immediately the closing bell rings. From the study, though the students rated the teachers as having more negative attitude in the teaching of technical drawing in the technical colleges, it was also discovered during the researcher's classroom observation of the teachers teaching technical drawing that most teachers had negative attitude and very few of them had positive attitude toward their teaching profession.

From the analysis of research question two; the students' perception reveals that technical drawing teachers were not effective in four out of seven indices of teachers' knowledge and skills in the teaching of technical drawing in technical colleges of Edo and Delta States. The students' perception could be a good report according to this study. Supporting this view, authors [16, 18] stated that students are the most qualified sources to report on the extent to which the learning experiences were productive, informative, satisfying, or worthwhile. They went further to opine that while opinions on these matters are not direct measure of teachers or course effectiveness, they are legitimate indicators of students' satisfaction, and there is substantial research linking students' satisfaction to effective teaching. In this same vein, authors [1, 9, 15] supporting this idea states that research studies provide the strongest evidence for the validity of students' ratings since these studies investigated the relationship between student ratings and student learning and there is consistently high correlation between students' ratings of the "amount learned" in the course and their overall ratings of the teachers and the course. Those who learn more gave their teachers high ratings [5].

However, students' rating is one of several forms of evaluation used to shed light on teachers' teaching effectiveness because, students want teachers that have "hardness of head but softness of heart" [10]. Students want teachers that know what they are talking about and also care about them.

\section{CONCLUSION AND RECOMMENDATIONS}

The findings support the conclusion that there are aspects of teachers' knowledge, attitude and skills in teaching technical drawing that is less than excellent and in need of further enhancement. If left unattended to, this could have a negative multiplier effect on students' performance in examinations in technical drawing. From the foregoing, it is recommended that the federal and state ministries of education in partnership with various stakeholders in the education sector in Edo and Delta States, Nigeria organize inservice training, seminars, workshops and conferences, where teachers can be groomed on teaching methodology and effective handling of students. Professional development keeps teachers effective and abreast of current issues in education, helps them implement innovations and refines their practices/approach.

\section{REFERENCES}

1. Abiola, O.-O. F. (2013). Students' Perception of Teachers' Factors in the Teaching and Learning of English Language in Nigerian Secondary Schools. Journal of Educational and Social Research. doi: 10.5901/jesr.2013.v3n3p173

2. Allport, G. W. (1935). Attitudes. In C. Murchison (Ed.), A handbook social psychology (pp. 798-844). New York: Russell \& Russell.

3. Barr, A. (1948). The Measurement and Prediction of Teaching Efficiency: A Summary of Investigations. The Journal of Experimental Education, 16(4), 203-283.

4. Bashir, H., Alias, M., Saleh, K.M. \& Halizah, A. (2017). Students' perceptions of their teachers' performance in teaching engineering drawing in Nigerian tertiary institutions. Path of Science, 3(10), 3001-3012. doi: 10.22178/pos.27-4 
5. Cohen, P. A. (1981). Student Ratings of Instruction and Student Achievement: A Meta-Analysis of Multisection Validity Studies. Review of Educational Research, 51(3), 281. doi: 10.2307/1170209

6. Dalley-Trim, L. (2007). Students' Observations and Perceptions of Teacher "Performances" in the Classroom. Australian Journal of Teacher Education, 32(1), 17-35. doi:

10.14221/ajte.2007v32n1.2

7. Dauda, B., Jambo, H. E., \& Umar, M. A. (2016). Students' Perception of Factors Influencing Teaching and Learning of Mathematics in Senior Secondary Schools in Maiduguri Metropolis, Borno State, Nigeria. Journal of Education and Practice, 7(20), 114-122.

8. Donahue, J. M. (1994). Student perceptions of their teachers, their school, and themselves as learners (Doctoral dissertation). Retrieved from https://lib.dr.iastate.edu/cgi/viewcontent.cgi?article=11693\&context=rtd

9. Duyar, I., Ras, N., \& Pearson, C. L. (2015). Analysis of teachers' task and extra-role performance under different autonomy regimes. International Journal of Productivity and Performance Management, 64(4), 499-522. doi: 10.1108/ijppm-06-2013-0103

10. Goldsmid, C. A., Gruber, J. E., \& Wilson, E. K. (1977). Perceived Attributes of Superior Teachers (PAST): An Inquiry into the Giving of Teacher Awards. American Educational Research Journal, 14(4), 423. doi: $10.2307 / 1162340$

11. Hanushek, E. A., \& Rivkin, S. G. (2006). Chapter 18 Teacher Quality. Handbook of the Economics of Education, 1051-1078. doi: 10.1016/s1574-0692(06)02018-6

12. Ibrahim, A.-W. (2014). The Students' Perception of Teachers' Classroom Effectiveness on Their SelfConcepts in Lagos Metropolis. Journal of Teaching and Teacher Education, 2(2), 133-141. doi: 10.12785/jtte/020209

13. Kurniati, I. \& Surya, E. (2017). Students' perception of their teacher teaching styles. International Journal of Sciences: Basic and Applied Research, 33(2), 91-98.

14. Modebelu, M. N., \& Nwakpadolu, G. M. (2013). Effective Teaching and Learning of Agricultural Science for Food Security and National Sustainability. Journal of Educational and Social Research. doi: 10.5901/jesr.2013.v3n4p161

15. OIRA. (n. d.). What's the use of student ratings of teaching effectiveness? Retrieved from http://institutionalresearch.syr.edu/wp-content/uploads/2018/10/Use.pdf

16. Scherer, R., Nilsen, T., \& Jansen, M. (2016). Evaluating Individual Students' Perceptions of Instructional Quality: An Investigation of their Factor Structure, Measurement Invariance, and Relations to Educational Outcomes. Frontiers in Psychology, 7, 1-16. doi: 10.3389/fpsyg.2016.00110

17. Sutcliff, C. (2011). Secondary Students' Perceptions of Teacher Quality (Doctoral dissertation). Retrieved from https://digitalcommons.georgiasouthern.edu/cgi/viewcontent.cgi?article=1391\&context=etd

18. Theall, M., \& Franklin, J. (1990). Student ratings of instruction: Issues for Improving practice. San Francisco: Jossey-Bass.

19. von Heiner R. (2009). Teaching Evaluation: Introduction and overview of research and practice of course evaluation at universities with a contribution to the evaluation of computer-based teaching. Bürgerstraße: Verlag Empirische Pädagogik. 